\title{
Alternatives as sources of semantic dependency*
}

\author{
Anamaria Fălăuş \\ University of the Basque Country
}

\begin{abstract}
The restricted distribution of the Romanian determiner vreun is puzzling in view of typologically familiar patterns of dependent indefinites. Focusing on its occurrences in modal and attitude contexts, I put forward a novel empirical generalization ('the epistemic constraint') and argue that its distribution is sensitive to epistemic alternatives. To account for this pattern, I endorse the unitary approach to polarity due to Chierchia $(2006,2010)$ and propose to derive the properties of vreun from its obligatory association with alternatives. The differences between vreun and other dependent indefinites are argued to follow from different conditions on the domain alternatives these items activate.
\end{abstract}

Keywords: alternatives; epistemic indefinites; polarity system; exhaustification

\section{Introduction}

This paper focuses on the properties of the Romanian determiner vreun, and has two objectives. First, it seeks to provide an adequate description of its restricted distribution. Refining previous observations in the literature (Farkas 2002, 2006), I argue that the occurrence of vreun in intensional contexts is sensitive to epistemic alternatives, and put forward a generalization that captures its use ('the epistemic constraint'). Second, we aim to provide an explanation for the observed pattern, in a way that situates vreun in a broader typology of dependent indefinites. The proposed account is couched in a unified, alternative-based approach to polaritysensitivity, due to Chierchia (2006 et seq.). In line with this theory, we reduce the differences between vreun and other dependent indefinites to essentially two factors: (i) the types of alternatives these items activate and (ii) the way these alternatives are factored into meaning by alternative-sensitive operators. The present paper can be regarded as part of a more general research program which aims to understand the parameters of variation among dependent indefinites and to offer a principled

* For helpful comments and suggestions on different versions of this paper, I wish to thank Maria Aloni, Luis Alonso-Ovalle, Gennaro Chierchia, Hamida Demirdache, Donka Farkas, Anastasia Giannakidou, Paula Menéndez-Benito, Orin Percus, and Lucia Tovena, as well as audiences at IGG 36, LSRL 40, SALT 20, LUSH, University of Göttingen and Institut Jean Nicod. All errors are my own, of course.

C2010 Anamaria Fălăuş 
Alternatives as sources of semantic dependency

explanation for the attested diversity (see e.g. Giannakidou 1997, to appear, Kratzer \& Shimoyama 2002, Chierchia 2006, Jayez \& Tovena 2006, 2007, Alonso-Ovalle \& Menéndez-Benito 2008, 2010, and references therein).

\section{Vreun as a dependent determiner}

The determiner vreun (MASC)/vreo (FEM) is a morphologically complex variant of the standard indefinite article un (MASC)/o (FEM), which combines with the morpheme vre- (from volere $>$ *vere 'want'), and occurs with singular countable nouns. As illustrated by the ungrammaticality of (1) below, the determiner vreun cannot occur in episodic sentences, i.e. qualifies as a 'dependent' or polaritysensitive $^{1}$ item.

(1) *Ana a văzut vreun prieten / vreo prietenă. Ana have.3SG seen VREUN friend / VREUN friend.FEM

In order to account for this restriction, we first need to identify the kind of dependency observed in the distribution of vreun. This is not an easy task, as already shown in Farkas 2002, because vreun seems to resist classification in typologically familiar patterns of dependent indefinites.

\subsection{Negative polarity contexts}

The first descriptive observation is that vreun clearly does the work of a negative polarity item (NPI) in Romanian: it occurs in all typical negative polarity contexts ${ }^{2}$, where NPI any or ever would be used, e.g. questions (2), the scope of weak downward-entailing operators like rarely (3), if -antecedents or negative verbs like doubt:

1 Assuming a broad definition of polarity-sensitive items, characterized by 'exclusion from positive assertions with simple past' (cf. Giannakidou 1997 et seq.). In this paper, I use the terms polaritysensitive and dependent indefinite interchangeably.

2 The distribution of vreun in the scope of clausemate sentential negation is more complex: as a result of the fact that Romanian is a strict negative concord language, i.e. the (morphologically negative) paradigm of n-words constitutes the default option in negative sentences. In Fălăuş 2009, I argue that this blocking effect does not constitute a valid counter-argument to an NPI-status for vreun, and show that the blocking can be overridden (i) in contexts where there is already an n-word in the sentence, or (ii) in order to convey domain widening. 
$\mathrm{Ai} \quad$ vreo conferinţă luna asta?

Have.2SG VREUN conference month this

'Do you have any conference this month?'

(3) Rar îmi dă vreo explicaţie despre ceea ce

Rarely me.DAT give.3SG VREUN explanation about DEM what

face.

do.3SG

'Rarely does (s)he give me any explanation on what (s)he's doing.'

In addition, vreun is also possible in non-negative polarity environments, a very common behavior for NPIs across languages (Haspelmath 1997). More specifically, the determiner vreun can occur in modal contexts, as in the following example, taken from Farkas 2002: 136:

E posibil ca Maria să se fi întâlnit cu vreun
be.3SG possible that Maria SUBJ REFL BE met with VREUN
prieten şi să fi rămas cu el în oraş.
friend and SUBJ BE remained with him in town
'It is possible that Maria met some friend and stayed with him in town.'

In (4), vreun occurs in the scope of the modal operator 'it's possible', and the sentence conveys that Maria might have met a friend, the speaker doesn't know which friend, and she might have stayed with him in town. A similar ignorance (or indifference) reading is triggered in Romanian by the existential free-choice item ( $\exists$-FCI) un NP oarecare (Săvescu-Ciucivara 2007), paraphrased in (5a):

\section{Maria trebuie să citească o carte oarecare.}

Maria must SUBJ read.3SG a book whatever

a. 'Maria must read a certain book, the speaker doesn't know/care which book.'

b. 'Maria must a read a book, any book is a possible option.'

Both vreun and un NP oarecare are existential elements, occurring in modal(ized) contexts, and signaling the speaker's lack of knowledge concerning the identity of the individual satisfying the existential claim. Despite this similarity, their distributions do not overlap, as illustrated by the ungrammaticality of vreun in the imperative in (6):

(6) Ia *vreo carte $/ \checkmark$ o carte oarecare!

Take vreun card / a card whatsoever

'Take some card (or other).' 
Alternatives as sources of semantic dependency

A more detailed empirical investigation reveals further distributional contrasts, which are unexpected given the patterns of polarity-sensitivity attested in the literature. In particular, the following set of examples indicates that vreun can occur under some modals (7), but not others (8):

$\mathrm{Cu}$ numele lui, trebuie să fie vreun aristocrat.

With name.DEF his must SUBJ be.3SG VREUN aristocrat

'Given his name, he must be some aristocrat.'

*Trebuie să iau vreun zbor spre Paris.

must SUBJ take.1SG VREUN flight to Paris

'I must take some flight to Paris.'

Likewise, vreun is possible under some attitude verbs (e.g. think, suppose, assume, hope), but not others (e.g. know, say, ask, insist, want):

(9) Sper să găsesc vreun zbor spre Paris. hope.1SG SUBJ find.1SG VREUN flight to Paris

'I hope to find a/some flight to Paris.'

*Vreau să iau vreun zbor spre Paris. want.1SG SUBJ take.1SG VREUN flight to Paris

'I want to take some flight to Paris.'

We have seen that the distribution of vreun presents interesting overlap between its use in negative polarity (i.e. downward-entailing) contexts, and certain nonpolarity contexts, where vreun conveys some form of ignorance. Whereas overlap per se is not surprising, its precise nature remains to be determined. In particular, we need a better understanding of the contrasts in (7)-(8) and (9)-(10). This is the goal of the next section, where I focus on non-negative contexts of occurrence and propose a novel descriptive generalization, dubbed 'the epistemic constraint', which captures the puzzling distribution of vreun.

\subsection{The epistemic constraint}

The examples above suggest that vreun occurs in a subset of intensional contexts (modals and attitude verbs). The intuition underlying the non-negative polarity use of vreun is made explicit in Farkas's work: 'the choice of vreun over the ordinary indefinite [...] stresses the uncertainty of the existence of a verifying value in the world of evaluation' (Farkas 2006: 19). Refining this observation, I argue that the distribution of vreun is governed by epistemic alternatives. More precisely, the epistemic determiner vreun is sensitive to what an epistemic agent, for our present 
purposes, the speaker ${ }^{3}$ holds to be true, as captured by the following generalization:

\section{THE EPISTEMIC CONSTRAINT}

Context of occurrence: Op [...vreun ... ]

Op $p$ entails that the speaker's epistemic alternatives include non $p$-worlds

According to the epistemic constraint in (11), vreun occurs in the scope of propositional operators that entail that not all of the speaker's epistemic alternatives are such that the proposition below the operator, $p$, is true. In other words, the speaker countenances (possibly unlikely) non $p$-worlds. Let me now illustrate how the generalization I propose captures the distribution of vreun under modal operators (sections 2.2.1 and 2.2.2) and under attitude verbs (section 2.2.3).

\subsubsection{The presumptive mood}

The epistemic constraint seeks to capture the intuition that vreun is restricted to contexts that are 'hypothetical', where the speaker communicates she is not in a position to rule out the possibility that the proposition containing vreun is false. The context that straightforwardly shows the role of this 'uncertainty' component is the presumptive mood, a mood specialized in conveying hypotheses, and one of the prototypical contexts of occurrence for vreun. Morphologically, it presents different paradigms, following the pattern modal (future/conditional form) $+b e+$ gerund (present reading)/past participle (past reading). Abstracting away from its properties (cf. Irimia 2008), the only point that is relevant for our present discussion is that presumptive forms always convey a meaning of indirect evidentiality: there is indirect evidence (typically inferential) that a certain state of affairs might hold/might have held. By using the presumptive, the speaker conveys that her assertion is only a hypothesis, i.e. she is not in a position to exclude that things might be/have been different. The presumptive plays a crucial role in the distribution of vreun, as

3 I set aside situations where there is more than one potential relevant epistemic agent and restrict the discussion to contexts where the epistemic agent is the speaker. Preliminary investigation on this issue indicates that vreun tends to be speaker-oriented, unlike e.g. algún (Alonso-Ovalle \& Menéndez-Benito 2010):

(i) *Mircea crede că Maria s-a întâlnit cu vreun prieten. El nu ştie cu cine, dar eu ştiu. Mircea thinks that Maria met VREUN friend. He doesn't know who, but I do.

A satisfactory resolution of this problem relies on a better understanding of the constraints governing the distribution of the presumptive forms (see section 2.2.1), where the identity of the epistemic agent also plays a role in the acceptability. The preliminary generalization is that whenever the embedded presumptive is possible, vreun is also possible, but more research is required before reaching firm conclusions on how the two factors are related. 
Alternatives as sources of semantic dependency

illustrated by the following contrast:

(12) Maşina porneşte greu dimineaţa.

'My car takes time to start up in the morning'.

a. *Are vreo problemă la motor.

have.3SG VREUN problem at engine

'It has some engine problem.'

b. $O \quad f i$ având vreo problemă la motor.

FUT2.3SG BE have.PRST.PART VREUN problem at engine

'It might have/ I guess it has some engine problem.'

The intended meaning of (12) is a hypothesis on the reason why the car doesn't start up easily, but despite this hypothetical meaning, clearly indicated by the context, vreun is ruled out in (12a). In contrast to this, as soon as present tense is replaced by the presumptive, vreun becomes acceptable (12b). Since presumptive forms can only be used in situations where the speaker entertains (possibly unlikely) non p-worlds, the epistemic constraint is automatically satisfied. It is therefore not surprising that the presumptive mood constitutes one of the most frequent contexts of use of vreun.

\subsubsection{Modal contexts}

The tight connection with the presumptive emphasizes the role of the non $p$-worlds component for the acceptability of vreun. A closely related set of environments involves modal operators. Romanian has two modal verbs, the possibility modal $a$ putea 'can' and the necessity modal a trebui 'must', which are used to express a wide range of modal meanings. The determiner vreun can occur under both these modals, but crucially, only when they are interpreted with respect to an epistemic modal base. To illustrate, consider the interaction with the necessity modal:

(13) Trebuie să fie vreun restaurant turcesc în cartier, must SUBJ be.3SG VREUN restaurant Turkish in neighborhood (sunt mulţi locuitori de origine turcă.) be.3PL many inhabitants of origin Turkish

'There must be some Turkish restaurant in the neighborhood (there are many inhabitants of Turkish origin).' 
a. *Trebuie să trimit vreun articol până mâine dimineaţă. must SUBJ write.1SG VREUN article by tomorrow morning 'I must send some paper by tomorrow morning.'

b. *Ca să fiu fericită, trebuie să mănânc zilnic vreo That SUBJ be.1SG happy, must SUBJ eat.1SG daily VREUN prăjitură. cake 'In order to be happy, I must have some cake every day.'

Sentence (13) has an epistemic construal and vreun is perfectly acceptable. In contrast to this, when the necessity modal has a deontic (14a) or bouletic (14b) construal, vreun cannot be used, even if the speaker is trying to convey that she is ignorant with respect to the identity of the value taken by the vreun-phrase. The obvious source for this contrast lies in the modal base and the kind of alternatives that are relevant for the interpretation of the modal operator, a state-of-affairs which corroborates the hypothesis on vreun's sensitivity to epistemic alternatives.

An interesting question that arises at this point concerns the way in which an epistemic modal satisfies the requirement in (11). On standard assumptions, the interpretation of an epistemic modal amounts to existential/universal quantification over epistemically accessible worlds. Hence, strictly speaking, an epistemic necessity modal like must conveys that in all worlds compatible with what the speaker knows, its complement proposition is true. This might look problematic for the epistemic constraint advocated so far. However, it has often been noted that in addition to quantification over epistemically accessible worlds, the meaning of an epistemic modal involves an indirect evidentiality component (e.g. von Fintel \& Gillies 2010) ${ }^{4}$. Simplifying, epistemic modals are sensitive to the type of evidence that is relevant for the truth of $p$ : upon using an epistemic modal, the speaker is not only conveying something about her beliefs, but also that she only has indirect evidence for her claim. As a result, this leaves open the possibility that direct evidence eventually contradicts $p$. This is the reason why epistemic modals cannot be used in contexts that set the value of $p$, and in particular when $p$ is established to be true, e.g. upon looking at pouring rain, we cannot utter something like It must be raining. In other words, the speaker's epistemic alternatives necessarily include (possibly unlikely) non $p$-worlds, a property that proves crucial for the distribution of vreun. Once we take into account the full meaning of an epistemic modal, we have ways to understand how this case falls under the epistemic constraint in (11).

4 The 'indirect evidence' requirement of epistemic modals is a complex and much debated issue, with no consensus on whether the restriction concerns evidence, knowledge or trustworthiness, or on whether this meaning component needs to be lexically encoded or rather derived as a conversational implicature. (see e.g. von Fintel \& Gillies 2010, Kratzer to be published, and Matthewson 2010). 
Alternatives as sources of semantic dependency

Summarizing, the empirical facts considered so far emphasise the importance of two factors (i) epistemic alternatives and (ii) the existence of non $p$-worlds. I now argue that this conclusion also holds for attitude contexts.

\subsubsection{Attitude verbs}

The acceptability of vreun in attitude contexts is once again sensitive to epistemic alternatives, as attested by its ungrammaticality under verbs of obligation:

$$
\begin{aligned}
& \text { *Roxana } m \text { - } a \text { rugat/mi-a cerut/ mi-a } \\
& \text { Roxana me-have.3SG asked/me-have.3SG requested/ me-have.3SG } \\
& \text { ordonat } \text { să aduc vreun cadou. } \\
& \text { ordered SUBJ bring VREUN present } \\
& \text { 'Roxana asked/requested/ordered me to bring some present.' }
\end{aligned}
$$

More interesting are attitude predicates whose interpretation involves an epistemic (or doxastic) modal base, on which we now focus. According to the generalization in (11), vreun occurs below operators which are incompatible with situations where their complement proposition is established to be true, i.e. where the speaker only entertains $p$-worlds. This captures in a straightforward way the non-occurrence of vreun in factive contexts:

$$
\begin{aligned}
& \text { *Ştiu că am vreun virus în calculator. } \\
& \text { know.1SG that have.1SG VREUN virus in computer } \\
& \text { 'I know I have some virus in my computer.' }
\end{aligned}
$$

Further evidence for the crucial role of the non p-worlds component in the acceptability of vreun comes from examples like (17) below:

$$
\begin{aligned}
& \text { Cred /Bănuiesc /Sunt convins /sunt sigur că } \\
& \text { Believe.1SG /Suppose.1SG /am.1SG convinced /am.1SG sure that } \\
& \text { am vreun virus în calculator. } \\
& \text { have.1SG VREUN virus in computer } \\
& \text { 'I think/suppose/I'm convinced/sure I have some virus in my computer.' }
\end{aligned}
$$

Predicates like think or assume allow for the possibility that their complement proposition be false. When we assert something like 'I think/suppose/assume $p$ ', we not only communicate that it is compatible with our beliefs that a certain state-ofaffairs holds (denoted by the complement proposition $p$ ), but also that we are not excluding the possibility that the proposition $p$ is false. Crucially, if the proposition under consideration is established to be true, the speaker cannot use think or assume. For example, in the pouring rain context, the speaker cannot truthfully utter $I$ 
think/assume it is raining. A similar ban against direct evidence establishing the truth of $p$ is involved in the case of operators like I'm convinced/sure. What is important to notice, in this connection, is that it is not the strength of the belief that matters, or else (17) should be unacceptable. Just like in the case of epistemic modals, what seems to be relevant is the existence of a (however slight) chance that things turn out to be different, i.e. further evidence could eventually contradict $p$; in other words, the speaker countenances non $p$-worlds ${ }^{5}$.

The contrast between verbs like think on the one hand and factives like know on the other hand does not suffice to motivate the (arguably) strong constraint in (11). In particular, one might wonder whether it is not enough for the operator to be (merely) compatible with the existence of non $p$-worlds among the epistemic alternatives, rather than requiring (in the present formulation entailing ${ }^{6}$ ) it. The distribution of vreun under volitional verbs shows that the answer to this question is negative, and supports the proposed epistemic constraint. In this connection, consider the contrast between the verbs want, which precludes the use of vreun in its complement (18), and hope, which allows it (19):

*Vreau să iau vreun zbor spre Paris. want.1SG SUBJ take.1SG VREUN flight to Paris

'I want to take some flight to Paris.'

Sper să găsesc vreun zbor spre Paris. hope.1SG SUBJ find.1SG VREUN flight to Paris 'I hope to find a/some flight to Paris.'

This contrast is surprising: both want and hope are non-factive predicates and express that the worlds in which the embedded proposition holds are ranked high with respect to the attitude holder's preferences. Crucially however, hope and want differ with respect to their epistemic properties, a distinction which plays a role in the acceptability of vreun. More precisely, Scheffler (2008) identifies an epistemic component in the meaning of hope, which only makes it compatible with situations where the truth of the embedded proposition is not established, a property that want lacks. The relevant contrast is given in (20), which shows that want is compatible

5 The acceptability of vreun in examples like (17) provides crucial evidence that we are not dealing with a nonveridical item, like Greek kanenas, discussed in detail in work by Giannakidou (1997 et $s e q)$. Whereas there is interesting distributional overlap between vreun and nonveridical items, the restriction to epistemic contexts, in the sense discussed here, is a significant empirical difference, which deserves a more detailed discussion than what I can do within the limits of this paper.

6 One might object to the formulation of the epistemic constraint in terms of entailment. Whereas this a reasonable concern, I think the case of volitionals indicates that a strong requirement along the lines of the one advocated here stands a better chance of capturing the facts. The account proposed for vreun (section 3) reformulates the epistemic constraint in a way which seeks to obviate this problem. 
Alternatives as sources of semantic dependency

with $p$ being established to hold (20a), while hope is not (20b):

(20) It is raining and

a. $\checkmark$ I want it to be raining/ $\checkmark$ that is what I want.

b. \# I hope it is raining/\#that is what $\mathrm{I}$ hope.

These examples show that knowledge of a fact, e.g. looking at pouring rain, makes the use of hope infelicitous to refer to this fact, a restriction which does not apply to want. In other words, whenever we use hope, we necessarily allow for non $p$-worlds among our beliefs, as required by the epistemic constraint in (11).

\subsection{Intermediate summary}

The discussion in this section provided evidence that the distribution of vreun in non-negative polarity contexts depends on the semantic properties of the embedding operator. In particular, I have proposed the epistemic constraint in (11), which holds that the (un)grammaticality of vreun is determined by two (closely connected) factors: (i) the epistemic (evidential) modal base and (ii) the existence of non $p$ worlds among the worlds in the modal base. This generalization enabled us to capture an otherwise puzzling set of empirical facts. Two caveats are in order. First, the description of the data is not exhaustive; in Fălăuş 2009, I adduce more evidence that any further distributional facts are amenable to one of the two categories discussed here (i) negative polarity contexts and (ii) 'epistemic' contexts, i.e. meeting the requirement in (11). Second, the account one provides for the (non-)occurrence of vreun ultimately relies on the details of the semantics assumed for the contexts under consideration. Admittedly, the discussion here abstracted away from many such details. However, by looking at things from this perspective, we uncovered an interesting pattern, which contributes to our knowledge of parameters of variation in the area of semantically dependent indefinites. The goal of the next section is to situate the observed pattern in a unified system of polarity and provide elements for an explanatory approach.

\section{Vreun in the polarity system}

In view of the facts we just reviewed, it should be clear that any analysis of vreun needs to account for the following set of (related) properties:

(P1) dependency - the occurrence of vreun in sentences like (1) does not lead to some form of contextual inappropriateness, but rather to plain ungrammaticality. What is the source of this restriction? 
(P2) similarities and differences with other elements in the polarity system, in particular NPIs and $\exists$-FCIs, like Romanian un NP oarecare. Where should we situate vreun in the landscape of dependent indefinites?

(P3) the epistemic constraint - why is vreun restricted to epistemic contexts?

In order to address these questions, I endorse and build on the unified account of polarity developed by Chierchia (2006 et seq.), which I briefly review in section 3.1 below. We will see that this framework offers a principled explanation for the dependency of polarity items (P1), by assuming an obligatory association with alternatives. Next, building on the elements responsible for cross-linguistic variation in this framework, I propose a modification that allows us to situate vreun in a broader typology of dependent indefinites (P2). Finally, in section 3.3, I focus on the epistemic constraint and explore a way to tackle this issue (P3).

\subsection{A unified approach to polarity}

The main intuition underlying the use of vreun, already present in Farkas 2002, is that we are dealing with an alternative-introducing element. In order to implement this intuition, I pursue an alternative-based approach, due to Chierchia (2006), which seeks to provide a unified analysis for attested polarity patterns, by making use of a small set of parameters of variation. Building on insights in Kadmon \& Landman 1993, Krifka 1995, Lahiri 1998 and Kratzer \& Shimoyama 2002, Chierchia (2006 et

seq.) develops a unified account of the phenomenon of polarity, embedded within a more general theory of scalar implicatures. The main hypothesis is that all members of the polarity system share the property of being existentially quantified elements, which obligatorily activate alternatives. What makes a polarity item dependent, as opposed to, say, a simple indefinite, is the fact that the alternatives it brings in must be used for meaning enrichment. One of the crucial assumptions in this connection concerns the way meaning enrichment is achieved. In line with Chierchia 2006, Fox 2007, and Chierchia, Fox \& Spector to appear, among others, it is assumed that strengthened interpretations can be generated via a grammatical device, i.e. the insertion of an exhaustivity operator $\mathrm{O}$, roughly akin to only:

$$
\llbracket O \rrbracket\left(A l t_{\langle\mathrm{st}, \mathrm{t}\rangle}\right)\left(p_{\langle\mathrm{s}, \mathrm{t}\rangle}\right)(w)=1 \text { iff } p(w)=1 \wedge \forall q \in \operatorname{Alt}(p)[q(w)=1 \rightarrow p \subseteq q]
$$

According to the definition in (21), the exhaustivity operator responsible for strengthening applies to a proposition $p$ (the prejacent) and the set of its (propositional) alternatives $(A l t(p))$ and negates all stronger alternatives to $p$.

Getting back to the phenomenon of polarity, the present theory posits the following division of labor: the alternatives activated by polarity items trigger the insertion of an exhaustivity operator, a syntactic process. The semantic component evaluates 
Alternatives as sources of semantic dependency

the result of exhaustification, and determines whether it is coherent. If the result is both syntactically and semantically well-formed, the polarity item is licensed. If this is not the case, the result is ungrammatical. This is a property shared by all types of polarity items. Variation in the polarity system results from two interconnected factors (i) nature of alternatives and (ii) modes of exhaustification. Simplifying, depending on the types of alternatives polarity items introduce (domain or scalar), and the way exhaustification proceeds, we can derive the properties of the various subclasses of polarity items (e.g. negative polarity items, 'universal' and existential free-choice items or minimizers like budge an inch), which are therefore wholly reduced to the logical interaction of their lexical meaning and the ensuing implicatures. I will not get into the details of this theory, and refer to Chierchia's work, where the aforementioned assumptions are extensively discussed and motivated. Instead, let us now restrict our attention to the analysis proposed for existential dependent items (e.g. $\exists$-FCIs like Italian un NP qualunque) and show how the proposal can be extended to capture the properties of vreun.

\subsection{The area of existential dependent indefinites}

One thing that is clear concerning the interpretation of vreun is that we are dealing with an existential element, conveying speaker's ignorance with respect to the identity of the individual which satisfies the existential claim. This ignorance reading is characteristic of a large and heterogeneous class of dependent indefinites crosslinguistically, often referred to as epistemic or modal indefinites (see e.g. Kratzer \& Shimoyama 2002, Chierchia 2006, Jayez \& Tovena 2006, 2007, Alonso-Ovalle \& Menéndez-Benito 2008, 2010, and references therein). Restricting the discussion to this particular area of the polarity system, let us focus on how the theory derives the core properties of these indefinites. Consider the following sentence, with the Italian $\exists$-FCI uno studente qualunque:

(22) Gianni deve interrogare uno studente qualunque Gianni must examine a student whatsoever

Intuitively, we interpret (22) as saying that Gianni must examine a student and any student in the relevant domain is a possible option. How does this meaning come about? Taking morphology at face value, Chierchia argues that there are two components involved in the interpretation of an $\exists$-FCI: the indefinite article (un) and the free-choice item (qualunque). Both elements activate alternatives, requiring exhaustification. The indefinite part activates scalar alternatives, triggering an 'exactly' implicature. This is similar to the way a sentence like 'I bought a book' implicates 'I bought no more than one book'. The free-choice element activates domain alternatives, which are responsible for the regular 'free-choice' implicature: 
any member of the relevant set is an admissible option. Putting the two implicatures together gives rise to a clash, which can only be obviated in the presence of a modal operator, like deve in (22) above. The proposal just sketched thus offers a principled explanation for the restriction of $\exists$-FCI to modal contexts. Importantly, this follows from the core of the polarity system: the nature of alternatives (scalar and domain) and the way they are factored into meaning via exhaustification.

With this background in mind, let us now return to Romanian and see how the account can capture the distribution of vreun, which I have argued to be sensitive to (a subset of) modal operators. For this, it is useful to contrast vreun with the Romanian $\exists$-FCI un NP oarecare. In particular, we are interested in what seems to be a systematic difference between $\exists$-FCIs like un NP oarecare/qualsiasi/quelconque and 'epistemic' items like algún, quelque or vreun, as originally pointed out by Jayez \& Tovena (2006), and later discussed in Alonso-Ovalle \& Menéndez-Benito 2008, 2010 and Fălăuş 2009. More precisely, these studies have revealed yet another dimension along which existential dependent indefinites vary, which concerns the extent of variation ('freedom of choice') among the members of the restriction set. It has been shown that $\exists$-FCIs like un NP qualunque/ oarecare sustain TOTAL variation, requiring that all relevant alternatives in the quantificational domain should qualify as possible options. This behavior can be readily observed by considering the inappropriateness of the continuation in (23), explicitly excluding one possible value:

Vino la petrecere cu un coleg oarecare, \# dar nu cu Paul.

'Come to the party with a colleague whatsoever, \# but not with Paul.'

In contrast to this, items like French quelque, Spanish algún or Romanian vreun associate with PARTIAL variation: some, but not necessarily all alternatives qualify as possible options, as illustrated by the possible continuation in (24) below:

E posibil ca Irina să se fi întâlnit cu vreun prieten, be.3SG possible that Irina SUBJ REFL be met with VREUN friend, dar nu poate fi Luca, tocmai l-am văzut.

but NEG can be Luca, just CL-have.1SG seen

'It's possible that Irina met some friend, but it cannot be Luca, I have just seen him.'

How can we account for this difference between un NP oarecare and vreun, or more broadly, how does this systematic contrast fit with the rest of the polarity system? Building on a proposal in Alonso-Ovalle \& Menéndez-Benito 2008, 2010, but making use of the 'regular' elements responsible for variation on the approach to polarity defended here, namely types of alternatives, I submit that total versus partial variation stems from different sizes in the domain alternatives we consider for 
Alternatives as sources of semantic dependency

exhaustification: if the domain alternatives are non-minimal, the resulting meaning is a TOTAL free-choice interpretation: there is a single individual satisfying the existential claim, and all relevant alternatives qualify as possible options ( $u n N P$ oarecare); if the domain alternatives to which we apply the exhaustification operator are minimal (singletons), the resulting meaning is PARTIAL variation - some, but not necessarily all, alternatives qualify as possible options (vreun).

In order to illustrate how the posited difference in domain alternatives determines the extent of variation, consider the example in (25), with the two types of existential items under a possibility modal:

Poate găsesc o carte oarecare ${ }^{7}$ /vreo carte (despre Brâncuşi).

Maybe find.1SG a book whatsoever /some book about Brâncuşi

Making use of very simplified representations, which are however sufficient for our present purposes, the difference between un NP oarecare and vreun can be understood along the following lines. The LF representation in (26a) leads to the assertion in (26b):

$$
\begin{array}{ll}
\text { a. } & \diamond\left[\operatorname{a~book}_{\mathrm{i}}\left[\mathrm{I} \text { find } \mathrm{t}_{\mathrm{i}}\right]\right] \\
\text { b. } & \diamond \exists x \in D[\operatorname{book}(x) \wedge 1(x) \wedge \operatorname{find}(I, x)]
\end{array}
$$

This is exactly what we would have with a simple indefinite. In addition, un oarecare / vreun activate two kinds of alternatives, with each of these sets of alternatives calling for the insertion of an exhaustivity operator. Recall from the definition in (21) above that the exhaustivity operator applies to a proposition and the set of its propositional alternatives. In order to obtain these propositional alternatives, we replace the polarity item, which is an existential quantifier, with other members from the relevant domain of quantification $D$. Assuming that $D$ contains three books, $\{b 1, b 2, b 3\}$, and following Chierchia's notation, I represent the set of alternatives to the original assertion using disjunction of propositions $a, b$ and $c$, where 'a' stands for find $(I, b 1)$, 'b' stands for find $(I, b 2)$, 'c' stands for find(I,b3). The representation of the sentence in (25), with the exhaustivity operators corresponding to the two types of alternatives, amounts to (27) below:

$$
\begin{array}{ll}
\text { a. } & \mathrm{O}_{\text {dom-alt }} \mathrm{O}_{\text {sc-alt }}[\diamond \exists x \in \mathrm{D}[\operatorname{book}(\mathrm{x}) \wedge 1(\mathrm{x}) \wedge \text { find }(\mathrm{I}, \mathrm{x})]]^{8} \\
\text { b. } & \mathrm{O}_{\text {dom-alt }} \mathrm{O}_{\text {sc-alt }} \diamond(a \vee b \vee c)
\end{array}
$$

7 An accurate example with un NP oarecare under a possibility operator would actually involve a deontic or an ability modal, which both disallow vreun. This simplification does not bear directly on the illustration of total vs partial variation.

8 For expository reasons, we set aside other possible configurations (cf. Chierchia 2010). Note that the scope of the exhaustification operators with respect to the possibility modal determines the strength of the scalar implicature, which can have a stronger (resulting from $O_{\text {dom-alt }} O_{s c-a l t} \diamond(a \vee b \vee c)$ ) or a weaker effect $\left(O_{\text {dom-alt }} \diamond O_{s c-a l t}(a \vee b \vee c)\right)$ 
As far as scalar alternatives are concerned, the two indefinites behave identically, and activate propositional alternatives of the kind 'I find two books', 'I find three books' etc., as in (28a):
a. Scalar-alternatives $=\{\diamond \exists x \in \mathrm{D}[\operatorname{book}(x) \wedge \mathrm{n}(x) \wedge$ find $(\mathrm{I}, x)]: n \in N\}$
b. $\mathrm{O}_{\text {sc }- \text { alt }}[\diamond \exists x \in \mathrm{D}[\operatorname{book}(x) \wedge 1(x) \wedge$ find $(\mathrm{I}, x]]$
c. $\diamond \exists x \in \mathrm{D}[\operatorname{book}(x) \wedge 1(x) \wedge$ find $(\mathrm{I}, x)] \wedge \neg \diamond \exists x \in \mathrm{D}[\operatorname{book}(x) \wedge 2(x) \wedge$ find $(\mathrm{I}, x)]$
d. $\mathrm{O}_{\mathrm{sc}-\text { alt }}(\diamond(a \vee b \vee c))=\diamond(a \vee b \vee c) \wedge \neg \diamond(a \wedge b) \wedge \neg \diamond(a \wedge c) \wedge \neg \diamond(b \wedge c)$

We exhaustify with respect to these alternatives, by inserting the exhaustivity operator (28b), which leads to the exclusion of all stronger alternatives. Consequently, we end up with the scalar, 'exactly' implicature, roughly equivalent to the representation in (28c), or, in our toy model, (28d). Nothing surprising thus far. At this point, it might be easier to grasp the difference between un NP oarecare and vreun if we put aside the scalar implicature. The scalar component is ultimately responsible for the existential interpretation, but in the remainder of the discussion, we will be exclusively concerned with the free-choice implicature.

Let us now focus on domain alternatives, where I have posited a difference between un NP oarecare and vreun. In particular, I assume that (i) non-minimal domain alternatives (abbreviated as MAX) lead to total variation and (ii) minimal domain alternatives (MIN) are responsible for partial variation. The alternative sets generated on the basis of the two kinds of domain alternatives are schematized in (29):

a. Domain alternatives we consider for exhaustification:
i. NON-MINIMAL $(\mathrm{MAX})^{9}$ $\diamond(a \vee b) \quad \diamond(b \vee c) \quad \nabla(a \vee c)$
ii. MINIMAL (MIN) $\diamond a \quad \diamond b \quad \nabla c$

b. Exhaustified domain alternatives - 'second-order' exhaustification:
i. Exhaustified MAX $\diamond(a \vee b) \wedge \neg \vee c \quad \diamond(a \vee c) \wedge \neg \diamond b \quad \diamond(b \vee c) \wedge \neg \vee a$
ii. Exhaustified MIN
$\diamond a \wedge \neg \vee b \wedge \neg \vee c \quad \diamond b \wedge \neg \vee a \wedge \neg \vee c \quad \vee c \wedge \neg \vee a \wedge \neg \diamond b$

In (29a), we have the plain domain alternatives activated by each of the two dependent indefinites under consideration. The sets of alternatives in (29b) are the exhaustified version of the (plain) domain alternatives in (29a), and are obtained

9 In Fălăuş 2009, the set of domain alternatives associated with $\exists$-FCIs also includes minimal alternatives, i.e. MAX $=\{(a \vee b),(b \vee c),(a \vee c), a, b, c\}$. However, Chierchia (2010) shows that the presence of minimal domain alternatives doesn't affect the resulting meaning. 
Alternatives as sources of semantic dependency

by attaching $\mathrm{O}$ in front of each of the alternatives in MAX/MIN. The effect of exhaustifying an alternative, e.g. $\diamond \mathrm{a}$ with respect to the original assertion $\diamond(\mathrm{a} \vee \mathrm{b} \vee \mathrm{c})$ is to produce alternatives of the form $\checkmark \mathrm{a} \wedge \neg \vee \mathrm{b} \wedge \neg \vee \mathrm{c}$ (i.e. 'only $a$ is possible'). Things work in a similar manner for all other alternatives in MAX and MIN. ${ }^{10}$ Working things out, we compute the enriched meaning of (25), by putting together the assertion with the negation of the exhaustified alternatives:

Assertion + Free-choice implicature

a. i. NON-MINIMAL DOMAIN ALTERNATIVES (MAX)

$$
\begin{aligned}
& \mathrm{O}_{\max } \diamond(a \vee b \vee c)= \\
& \diamond(a \vee b \vee c) \wedge(\diamond(a \vee b) \rightarrow \diamond c)^{11} \wedge(\diamond(a \vee c) \rightarrow \diamond b) \wedge(\diamond(b \vee c) \rightarrow \\
& \diamond a)=\diamond a \wedge \diamond b \wedge \diamond c \quad \Rightarrow \text { TOTAL VARIATION }
\end{aligned}
$$

ii. MINIMAL DOMAIN ALTERNATIVES (MIN)

$$
\begin{aligned}
& \mathrm{O}_{\mathrm{MIN}} \diamond(a \vee b \vee c)= \\
& (\diamond a \rightarrow(\diamond b \vee \diamond c)) \wedge(\diamond b \rightarrow(\diamond a \vee \diamond c)) \wedge(\diamond c \rightarrow(\diamond a \vee \diamond b))= \\
& (\diamond a \wedge \diamond b) \vee(\diamond a \wedge \diamond c) \vee(\diamond b \wedge \diamond c) \quad \Rightarrow \text { PARTIAL VARIATION }
\end{aligned}
$$

Exhaustification over non-minimal domain alternatives, given in (30a-i), results in standard free-choice effect, requiring that each alternative of $a, b$ and $c$ be a possibility (TOTAL VARIATION). In contrast to this, the enriched meaning obtained by exhaustification over minimal domain alternatives, in (30a-ii), requires that if some alternative is true, at least some other must be. To put it differently, at least two of the alternatives $a, b$ and $c$ are true in some world, but not necessarily all of them (PARTIAL VARIATION).

We thus obtain the effect of the anti-singleton constraint in Alonso-Ovalle \& Menéndez-Benito 2008, 2010 ${ }^{12}$, which sets apart $\exists$-FCIs like un NP oarecare from epistemic determiners like vreun. In the spirit of the approach I pursue, we implemented this parameter of variation as a requirement on domain alternatives (minimal versus non-minimal). The theory of polarity we endorsed can therefore

10 This step is a regular move in generating the free-choice implicature, which is obtained via 'secondorder' exhaustification (as argued in Fox 2007).

11 By straightforward tautological transformations, $\neg(\diamond(\mathrm{a} \vee \mathrm{b}) \wedge \neg \vee \mathrm{c})$ is equivalent to $\diamond(\mathrm{a} \vee \mathrm{b}) \rightarrow \diamond \mathrm{c}$, and similarly for all other exclusions.

12 Alonso-Ovalle \& Menéndez-Benito $(2008,2010)$ implement this restriction by assuming that algún introduces an anti-singleton subset selection function on the quantificational domain. The alternativebased proposal I pursue retains the basic insight that differences among dependent indefinites result from different operations on quantificational domains. At this point however, it is not entirely clear what is the source of the constraint responsible for total versus partial variation; further investigation on the properties of plural dependent items and possible competition between singular and plural forms will hopefully shed light on this matter. 
straightforwardly accommodate the total versus partial variation behavior, and reduce the observed properties to a small set of primitive switches.

\subsection{The epistemic constraint: a matter of competition? ${ }^{12}$}

The most challenging property of vreun, relevant for the typology of dependent items, lies in the restriction to contexts where the speaker countenances non $p$-worlds. As far as I know, vreun differs in this regard from all other dependent items discussed in the literature ${ }^{14}$, such as kanenas or algún, which can occur under non-epistemic modals. Whereas we have arguably managed to make sense of most properties of vreun, at this point, we still need to derive the epistemic constraint. I do not have a full-fledged explanation, but I would like to suggest a way to tackle the problem, in the spirit of the general line we are pursuing. On the present approach to polarity, any further restriction on the distribution of vreun should ultimately be reducible to a difference concerning (i) alternatives or (ii) modes of exhaustification. I now explore the possibility that the epistemic constraint in (11) can be reformulated as a condition on alternatives, i.e. the requirement in (31):

(31) One of the domain alternatives must stand a chance of being false

We have seen that vreun (and items like algún, quelque) differ from 'total' $\exists$-FCI in being associated with partial variation, requiring that not necessarily all members of the restriction set be possible values for the existential claim. Pursuing this line of thinking, assume that vreun imposes a stronger constraint, i.e. not only does vreun allow partial variation, but actually requires it:

Hypothesis: vreun rules out TOTAL VARIATION

Let us first see how we could implement this intuition within the general framework and then discuss its consequences for the distribution of vreun. Consider the sentence in (33):

$$
\begin{aligned}
& \text { E posibil să găsesc vreo carte (despre Brâncuşi). } \\
& \text { Be.3SG possible SUBJ find.1SG some book about Brâncuşi } \\
& \text { 'It's possible that I find some book about Brâncuşi.' }
\end{aligned}
$$

13 I owe this way of deriving the epistemic constraint to Gennaro Chierchia, to whom I'm grateful for helpful discussion and generous comments on the ideas presented here. Needless to say, all errors or inconsistencies are my own.

14 The determiner that seems to come closest to vreun in this regard is French singular quelque, discussed in detail in work by Jayez \& Tovena (2007). The fact that quelque is very uncommon in modern French makes it difficult to reach firm conclusions on the distributional overlap. 
Alternatives as sources of semantic dependency

Looking only at the relevant steps in the derivation, prior to exhaustification, the assertion and the alternatives generated on the basis of domain alternatives are as given in (34b-i). In addition, as a way of implementing the ban on total variation in (32), assume that the alternatives normally responsible for total variation (saying that each alternative is a possible option, i.e. $\diamond \mathrm{a} \wedge \diamond \mathrm{b} \wedge \triangleright \mathrm{c}$ ) get added to the set of alternatives we consider for vreun (34b-ii):

a. Assertion: $\mathrm{O} \diamond(a \vee b \vee c)$

b. Alternatives (i) Exhaustified MIN + (ii) Total Variation
i. $\diamond a \wedge \neg \diamond b \wedge \neg \diamond$
$\diamond b \wedge \neg \vee a \wedge \neg \vee c \quad \diamond c \wedge \neg \vee a \wedge \neg \diamond b$
ii. $\diamond a \wedge \diamond b \wedge \diamond c$

Exhaustification over the set of alternatives in (34b) yields the following result:
Assertion + implicatures:
a. $\mathrm{O}(\diamond(a \vee b \vee c))=$
$\diamond(a \vee b \vee c) \wedge \neg(\diamond(a \vee b) \wedge \neg \vee c) \wedge \neg(\diamond(a \vee c) \wedge \neg \diamond b) \wedge \neg(\diamond(b \vee c) \wedge$ $\neg \diamond a) \wedge \neg(\diamond a \wedge \diamond b \wedge \diamond c)$
b. $=(\diamond a \wedge \diamond b) \vee(\diamond a \wedge \diamond c) \vee(\diamond b \wedge \diamond c) \quad$ (= PARTIAL VARIATION)
$\wedge \neg(\diamond a \wedge \diamond b \wedge \diamond c)$

$$
(=\neg \text { TOTAL VARIATION) }
$$

The meaning we get for our model with three alternatives is that at least two alternatives must be true in some world, but no more than two are (they cannot all be true). This entails that one of the alternatives must be false (31). This requirement can only be satisfied in partial variation models ${ }^{15}$. What are the consequences for the distribution of vreun? Arguably, epistemic modals satisfy this requirement, just like other operators subsumed under the epistemic constraint in (11), in virtue of the fact that they necessarily allow for the (however unlikely) possibility that their complement proposition be false. In contrast to this, deontic modalities cannot meet the requirement imposed by vreun: if a proposition $p$ is a deontic necessity, it has to be true in every world that conforms to the relevant set of obligations. Similarly, permission modals are fully compatible with total variation models, as shown by the inference of free-choice permission (e.g. Fox 2007): 'You' re allowed to eat the cake or the ice-cream' implicates 'you're allowed to eat the cake and you're allowed to eat the ice-cream'. In other words, each disjunct is a possible option, a situation which gives rise to a clash with the partial variation requirement imposed by vreun. In contrast to this, the 'total variation' $\exists$-FCI un NP oarecare is perfectly acceptable under deontic operators, as expected under the present assumptions.

Summarizing, there are two components to the proposal for vreun. First, we assume a strong competition with un NP oarecare, which we implement as a requirement to explicitly exclude the total variation inference. This allows us to make

15 A similar conclusion holds for necessity modals. 
sense of the epistemic constraint as a condition on domain alternatives. Second, once we take this step, the requirement imposed by vreun is arguably met in epistemic contexts, but gives rise to a clash with deontic modalities. Consequently, the restricted distribution of vreun comes out as the result of the interaction with the lexical semantics of modal operators ${ }^{16}$. The considerations above are preliminary in many respects, but hopefully they can be fleshed out to support the idea we are pursuing.

\section{Conclusions}

Summarizing, I have argued that the distribution of vreun in non-negative polarity contexts is sensitive to (speaker's) epistemic alternatives, and proposed a generalization that brings together a puzzling set of environments (the epistemic constraint). Next, we situated this pattern of use within a general typology of dependent indefinites, couched in an alternative-based theory of polarity, developed by Chierchia (2006 et seq.). On the present proposal, vreun shares with all other polarity-sensitive elements the property of being an existentially quantified term, whose restricted distribution is due to obligatory activation of alternatives. The presence of these alternatives triggers the insertion of the exhaustivity operator ${ }^{17}$, which must eliminate all stronger alternatives consistently. If the result is structurally ill-formed or semantically deviant, the polarity item is ungrammatical. This line of thinking thus captures vreun's dependent character (P1) in a principled manner, by making use of an exhaustification mechanism which has been independently argued for. Next, we can situate vreun in the polarity system, and understand its similarities and differences with other dependent indefinites (P2). In particular, vreun shares with existential free-choice items the property of activating two types of alternatives: domain alternatives (whose recursive exhaustification leads to the free-choice behavior) and scalar alternatives (responsible for the absence of universal readings). In addition, I have argued that vreun is associated with partial variation, as a result

16 Recent cross-linguistic work (Port 2010) shows that total versus partial variation behavior is not an inherent property of classes of dependent indefinites, but rather depends on the type of modal in the context of occurrence, thus supporting the correlation observed in Romanian.

17 More precisely, vreun selects for the weak exhaustification operator in (ii), responsible for NPI behavior:

(ii) $O(p, A L T(p))=O(p, A L T(p))$, if $[p \nsubseteq \cap A L T(p)] \rightarrow[O(p, A L T(p)) \subset p] ; \perp$, otherwise.

According to (ii), the operator will be defined and lead to exhaustification (cf. (21) above) in two situations: either if $p$ entails the conjunction of all true alternatives to $p$ (as arguably the case in all downward-entailing contexts), or if the exhaustification of $p$ asymmetrically entails (i.e. narrows down) $p$, that is, if we obtain a strengthened meaning (Chierchia 2010). This straightforwardly captures the NPI behavior of vreun, which we had to set aside due to space limitations. 
of the fact that it activates minimal domain alternatives (a property arguably shared by algún, quelque, un qualche). Finally, the restriction to epistemic contexts (P3), which sets vreun apart from all other dependent items described in the literature, can be regarded as resulting from competition with the 'total' $\exists$-FCI. The effect is that vreun imposes strong constraints on its quantificational domain, which in turn make vreun compatible with 'partial variation' models only.

The predictions and consequences of these hypotheses need to be further investigated, and there are both empirical and theoretical issues to be dealt with, some of which I have mentioned along the way. Similarly, the discussion in this paper did not touch upon other possible accounts, nor provided a systematic comparison between vreun and other dependent indefinites. Despite these limitations, the Romanian pattern we investigated contributes to our knowledge of dimensions of variation among semantically dependent indefinites, and as such constitutes progress on our way to a principled explanation for the attested diversity. The proposed analysis captures the intuition that alternatives are the key to understanding the properties of vreun, which have been shown to fit into a tightly regulated system. The consideration of the Romanian pattern within this general theory of polarity is mutually beneficial. On the one hand, the framework enables us to situate vreun in a typological perspective and account for its properties by making use of elements of variation which are arguably responsible for other polarity behaviors, thus making vreun less puzzling. On the other hand, if our proposal is on the right track and the system can be shown to fully accommodate vreun, this provides empirical and conceptual support to the present alternative-based approach, which builds into grammar the tight connection between the meaning of polarity items and their contexts of use.

\section{References}

Alonso-Ovalle, Luis \& Paula Menéndez-Benito. 2008. Minimal domain widening. In Natasha Abner \& Jason Bishop (eds.), Proceedings of the 27th West Coast Conference on Formal Linguistics, 36-44. Somerville, MA: Cascadilla Proceedings Project.

Alonso-Ovalle, Luis \& Paula Menéndez-Benito. 2010. Modal indefinites. Natural Language Semantics 18(1). 1-31. doi:10.1007/s11050-009-9048-4.

Chierchia, Gennaro. 2006. Broaden your views. implicatures of domain widening and the spontaneous logicality of language. Linguistic Inquiry 37(4). 535-590. doi:10.1162/ling.2006.37.4.535.

Chierchia, Gennaro. 2010. Meaning as inference: the polarity system. Ms.

Chierchia, Gennaro, Danny Fox \& Benjamin Spector. to appear. The grammatical view of scalar implicatures and the relationship between semantics and pragmatics. In Claudia Maienborn, Klaus von Heusinger \& Paul Portner (eds.), 
Semantics: An international handbook of natural language meaning, Berlin: Mouton de Gruyter.

Fălăuş, Anamaria. 2009. Polarity items and dependent indefinites in Romanian: University of Nantes dissertation.

Farkas, Donka. 2002. Extreme non-specificity in Romanian. In C. Beyssade et al (ed.), Romance languages and linguistic theory 2000, 127-153. Amsterdam/Philadelphia: John Benjamins.

Farkas, Donka. 2006. Free choice in Romanian. In Betty J. Birner \& Gregory Ward (eds.), Drawing the boundaries of meaning, Neo-Gricean studies in pragmatics and semantics in honor of Laurence R. Horn, 71-94. Amsterdam: John Benjamins.

von Fintel, Kai \& Anthony Gillies. 2010. Must... stay... strong! Natural Language Semantics 18(4). 351-383. doi:10.1007/s11050-010-9058-2.

Fox, Danny. 2007. Free choice disjunction and the theory of scalar implicatures. In Uli Sauerland \& Penka Stateva (eds.), Presupposition and implicature in compositional semantics, 71-120. Palgrave Macmillan.

Giannakidou, Anastasia. 1997. The landscape of polarity items: University of Groningen dissertation.

Giannakidou, Anastasia. to appear. Negative and positive polarity items: licensing, compositionally and variation. In Claudia Maienborn, Klaus von Heusinger \& Paul Portner (eds.), Semantics: An international handbook of natural language meaning, Berlin: Mouton de Gruyter.

Haspelmath, Martin. 1997. Indefinite pronouns. Oxford: Oxford University Press.

Irimia, Monica. 2008. Romanian evidentiality. Paper presented at Going Romance 2008.

Jayez, Jacques \& Lucia Tovena. 2006. Epistemic determiners. Journal of Semantics 23. 217-250. doi:10.1093/jos/ffl002.

Jayez, Jacques \& Lucia Tovena. 2007. Evidentiality and determination. In Proceedings of Sinn und Bedeutung, vol. 12, 271-286.

Kadmon, Nirit \& Fred Landman. 1993. Any. Linguistics and Philosophy 16(4). 353-422. doi:10.1007/BF00985272.

Kratzer, Angelika. to be published. The notional category of modality. In Collected papers on modals and conditionals, Oxford University Press.

Kratzer, Angelika \& Junko Shimoyama. 2002. Indeterminate pronouns: The view from Japanese. In Yukio Otso (ed.), Proceedings of the third Tokyo conference on psycholinguistics, Tokyo: Hituzi Syobo.

Krifka, Manfred. 1995. The semantics and pragmatics of polarity items. Linguistic Analysis 25. 209-257.

Lahiri, Utpal. 1998. Focus and negative polarity in Hindi. Natural Language Semantics 6(1). 57-123. doi:10.1023/A:1008211808250. 
Alternatives as sources of semantic dependency

Matthewson, Lisa. 2010. Evidential restrictions on epistemic modals. Paper presented at the Workshop on Epistemic Indefinites, Göttingen.

Port, Angelika. 2010. Irgend-indefinites and specificity. Talk given at 'Determiners: reference and degree of knowledge', Paris VII.

Săvescu-Ciucivara, Oana. 2007. Oarecare indefinites are not just any indefinites. In Alexandra Cornilescu et al. (ed.), Pitar mos: A building with a view. papers in honour of Alexandra Cornilescu, Bucharest.

Scheffler, Tatjana. 2008. Semantic operators in different dimensions: UPenn dissertation.

\author{
Anamaria Fălăuş \\ University of the Basque Country (UPV-EHU) \\ Departamento de Lingüística y Estudios Vascos, Facultad de Letras \\ Paseo de la Universidad 5, Vitoria-Gasteiz 01006, España \\ anamariafalaus@gmail.com
}

